\title{
What Determines Incumbent Auditors' Information Systems Design And Implementation Consulting Fees?
}

\author{
Ho Young Lee (E-mail: hoyounglee@mail.unomaha.edu), University of Nebraska
}

\begin{abstract}
This study examines determinants of demand for incumbent auditors' information systems design and implementation consulting services. While there was no evidence on how the services may affect auditor independence, opponents of allowing the service argue that auditors who provide the financial information systems consulting services may lower audit quality, reducing investor confidence in markets. The results indicate that while $R \& D$ expenditures, auditors' industry specialization, and auditor tenure are positively associated with demand for the information systems consulting, there is no evidence that accounting discretion and audit committee effectiveness are associated with demand for the information systems consulting.
\end{abstract}

\section{Introduction}

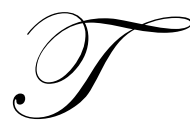

his study examines determinants of the purchase of auditors' financial information systems design and implementation consulting services by SEC audit clients. The SEC issued its auditor independence rules in November 2000, requiring disclosure of audit, the information systems design and implementation consulting, and other non-audit fees. Prior to the regulation, there were heated debates as to whether auditors should be allowed to provide the information systems consulting services for their audit clients. The SEC and investors were concerned about negative impact of auditors' information consulting services on auditor independence.

Former SEC Chairman Arthur Levitt criticized audit firms for using auditing as "a loss-leader retained as a foot in the door for higher-fee consulting services" (Levitt 1996). In particular, the financial information systems consulting was one of the most contentious areas during the rule setting among regulators and auditors. In the end, instead of prohibiting the information systems consulting, the SEC decided to require firms to disclose audit and non-audit fees to their auditors, effective on February 5, 2001. Furthermore, the new rule requires that the firms separately disclose auditors' information systems consulting (design and implementation) fees. Utilizing data obtained from the new mandatory disclosure, this study examines five determinants of demand for auditors' information systems consulting services. Particularly, the association between demand for incumbent auditors' information systems consulting services and research and development expenditures, auditor industry specialization, auditor tenure, managers' accounting discretion, and audit committee effectiveness are examined.

This study contributes to the understanding of the underlying mechanism in what determines demand for auditors' information systems design and implementation consulting services. Regulators and financial statement users will also find this information useful in assessing the impact of the above-discussed factors on demand for auditors' information systems consulting. The results indicate that demand for the information systems consulting services is positively associated with firms' investment in research and development, auditor industry specialization, and auditor tenure. However, neither managers' accounting discretion nor audit committee effectiveness is significantly associated with demand for the information systems consulting services.

Readers with comments or questions are encouraged to contact the author via email. 
The following section develops empirical hypotheses to investigate determinants of auditors' information consulting services. This is followed by a discussion of the research design and the test results. The last section concludes the paper.

\section{Development of Hypotheses}

As non-audit services continued to increase throughout the 1990s, the POB (Public Oversight Boards) formed the Panel on Audit Effectiveness in 1997, which issued a report in August 2000 making various recommendations for improving auditor independence. In addition, NYSE and NASDAQ formed the Blue Ribbon Committee (BRC) on Improving the Effectiveness of Corporate Audit Committees. The BRC recommended that the audit committee actively review all economic relationships between the external auditors and management. The SEC (2000a) expressed concern that increased fees from consulting and other services could increase the pressure on auditors to compromise their independence. After much consideration, the SEC incorporated the committees' recommendations in its auditor independence rules in November 2000 (SEC 2000b, SEC 2000c). In particular, the rule requires that firms separately disclose financial information systems design and implementation consulting (hereafter the ISC) fees from audit and other non-audit fees paid to incumbent auditors. However, thorough examination of what determines demand for incumbent auditors' ISC services has never been conducted. In this paper, five potential factors that affect demand for incumbent auditors' ISC are examined.

First, investment in research and development improves firm value (Sougiannis 1994). Davern and Kauffman (2000) also argue that implementation of information technology enhances productivity. Lucas et al. (1996) find that the introduction of a financial system at Merrill Lynch improves customer service and reduces costs. Banker et al. (2001) argue that appropriate use of information technology generates organizational innovations and redesigned business process. They find that investment in information technology is positively associated with productivity improvement. Organizational innovation and redesigning business process increase demand for ISC. Firms making a large contribution to the innovation process and research and development activities are likely to have higher demand for the ISC. Thus, it is hypothesized that there is a positive association between demand for the ISC services and research and development investment.

H1: Demand for auditors' information systems consulting is positively associated with investment in research and development.

Auditors with industry expertise provide their auditees with superior services and higher quality audits (Palmrose 1986; Craswell et al. 1995; DeFond et al. 2000). In addition, Taylor (2000) finds that industry specialist auditors assess auditees' inherent risk significantly less than non-industry specialist auditors due to greater knowledge and expertise. He also finds that specialist auditors are more confident about the appropriateness of their inherent risk assessments compared with non-specialist auditors. Thus, auditees who contract with industry specialist auditors are more likely to seek the ISC services from their auditors. Thus, it is hypothesized that auditors' industry specialization is positively associated with demand for the ISC services.

H2: Demand for auditors information systems consulting is positively associated with the level of client auditors' industry specialization.

The AICPA (1992) argues that auditors' expertise increases with auditor tenure and points out that the costs of providing services will decrease as auditors become more familiar with their clients. Thus, demand for auditors' information systems consulting services may be influenced by how long an auditor is retained in an engagement. As auditors have contracted with client firms for a longer period, auditors will be better able to identify potential information systems areas to improve. In support, St. Pierre and Anderson (1984) and Geiger and Raghunandan (2002) find that auditors of new clients commit more errors and experience higher legal risk than other auditors. In addition, two contracting parties with a common goal are expected to develop a long-term relationship (Greenberg and Baron 1997). Meixner and Welker (1988) also suggest that interaction between two contracting parties increases as tenure increases. Thus, as client managers have developed long-term relationship with their external auditors, client managers are likely to rely more on their auditors' advice over information systems. Subsequently, client managers may have greater demand for the ISC from their longer-term relationship auditors. Thus, positive association is expected between demand for the information systems consulting and auditor tenure. Thus, the following hypothesis will be examined. 
H3: Demand for auditors' information systems consulting is positively associated with tenure of client auditor.

Shockley (1981) argues that external auditors providing non-audit services have higher risk of losing independence than those not providing non-audit services. Knapp (1985) also argues that the purchase of management advisory services is negatively associated with auditor independence. The SEC originally considered banning the ISC services because auditor independence may be impaired as a result of the ISC services. However, firms were eventually required to provide only fee disclosure. The SEC believed that the disclosure would enable investors and the board of directors to judge for themselves whether auditor independence is impaired (Chung and Kallapur 2001). Consistent with the prior concern, if the ISC impairs auditor independence, client managers may have higher demand for ISC services with the hope of increasing accounting discretion. To examine whether client managers' accounting discretion is positively associated with demand for auditors' ISC, the following hypothesis is examined.

H4: Demand for auditors' information systems consulting is positively associated with discretionary accruals.

Audit committees are directly responsible for determining audit fees and independence arrangements. Menon and Williams (1994) and Beasley and Salterio (2001) argue that audit committees that do not include employees and gray directors and are active are effectively monitoring managers' activities. ${ }^{1}$ In relation to $\mathrm{H} 4$, if an increase in accounting discretion is one of the reasons for higher demand for the ISC, independent and active audit committees are expected to curtail demand for the ISC from firms' incumbent auditors. In order to examine whether effective audit committees reduce demand for the ISC from their incumbent auditors, the following hypothesis is examined.

H5: Demand for auditors' information systems consulting is negatively associated with audit committee effectiveness.

\section{Research Design}

\subsection{Measures of Variables}

Auditors' information systems design and implementation consulting, audit, and other non-audit fees are collected from the proxy statements available in the SEC's EDGAR database. As explanatory variables, the square root of client firms' research and development expenditures is used. To examine whether auditors' industry specialization is positively associated with demand for auditors' ISC services, MKSHARE is included representing auditors' industry market share. MKSHARE is computed using the proportion of client firms' sales revenue in an industry in a year. This proportion is computed using Compustat's research and active data, consisting of 20,941 firms. ${ }^{2}$ In this study, auditor tenure, AUDTEN, is the number of years that an auditor remains with the same client firm, beginning with 1981. Values of this variable range from a low of 1 to a high of 20.

To proxy for client managers' accounting discretion, discretionary accruals (DACCR) estimated using the Modified Jones model (Dechow et al. 1995). Dechow et al. (1995) and Bartov et al. (2001) show that the Modified Jones model is superior to other models for measuring discretionary accruals and detecting earnings management. Model parameters are estimated using cross-sectional rather than time-series data because this mitigates problems due to data unavailability for some estimation periods and structural changes in firms over time. It allows the model to control for changing economic conditions and events that affect discretionary accruals over time, as well as examine samples of firms with a short history reducing survivorship bias. For each firm i, for each year, discretionary accruals (DACCR) are estimated by subtracting the predicted level of non-discretionary accruals (NDAP) from total accruals (TA), i.e., DACCR $i=T A i-N D A P i{ }^{3}{ }^{3}$ If managers' incentives to increase accounting discretion are a potential reason for higher demand for the information systems consulting services (like SEC's and investors' concern), a positive association between demand for the ISC services and DACCR is expected. Independent and active audit committees are more likely to limit management's ability to benefit themselves at the expense of shareholders. Consistent with Abbott and Parker (2000, 2001), audit committee effectiveness is defined based on independence and activity (i.e., coded 1 if audit committees comprised entirely of outside, independent directors that meet at least twice annually, 0 otherwise).

This study controls for several factors (hereafter collectively called $C N T R L$ ). More complex firms may have greater demand for the ISC. In order to control for the complexity, number of business segments is utilized. Parkash and Venable (1993) suggest that demand for nonaudit services is expected to reflect knowledge spillovers 
from joint engagements. In order to control for any potential knowledge spillover effect from other services to the ISC services, the log of all fees other than information consulting fees paid to incumbent auditors are included. Lang and Lundholm (1993) suggest that large firms have incentives to disclose financial information more accurately to avoid litigation, which suggests that demand for the ISC may be positively associated with client size. To control for firm size, the log of total assets is included. Firm size may also control for client complexity (Copley et al. 1994). Chan et al. (1993) suggest that there be a causal relationship between client profitability and fees (both audit and non-audit fees) paid to auditors and find a significantly negative association between fees paid to auditors and return on equity. Thus, return on equity is included to control for the profitability.

\subsection{Empirical Model}

The following regression model is then used to test hypotheses $\mathrm{H} 1$ and $\mathrm{H} 5$ :

$I T F E E i=\alpha 0+\beta 1 R \& D i+\beta 2$ INDSPLSTi $+\beta 3 A U D T E N i+\beta 4 D A C C R i+\beta 5 A C E F F i+\sum_{k} \alpha_{k} C N R T L_{k i}+\varepsilon i$

All variables in the regression are as defined previously. If client managers' demand for information systems consulting increases significantly due to research and development activities, $\beta 1$ will be positive and statistically significant. If industry specialization and auditor tenure increase demand for auditors' ISC services, positive and statistically significant $\beta 2$ and $\beta 3$ are expected. If client managers' demand for information systems consulting increases significantly in order to increase accounting discretion, $\beta 4$ will be positive and significant. Finally, if effective audit committees have reason to believe that auditors' ISC services compromise auditor independence, managers' demand for auditors' ISC services will be curtailed by effective audit committees and therefore $\beta 5$ is expected to be negative and significant.

\section{Empirical Tests}

\subsection{Sample Selection}

The sample selection begins by selecting all active firms (excluding ADRs) on Standard and Poor's Compustat database that have contracted with an auditor and that have fiscal year end from October 2000 though March 2001. Financial institutions are eliminated (i.e., those in SIC 6000 through 6999). Next, the sample is required to have all variables used in the regression, which reduces the sample to 1,631. Finally, the sample is also required to disclose fees paid to incumbent auditors and audit committee characteristics in their proxy statements, which leaves the final sample of 1,081. The proxy statements in the EDGAR database of the SEC website is used to collect the fees and audit committee characteristics.

\subsection{Descriptive Statistics}

Descriptive statistics for variables used in the regression are presented in TABLE 1 . For the 1,081 sample firms, the table shows that the mean of the ISC fees is $\$ 0.434$ million. Mean value of log other fees (i.e., audit and other fees combined) are $\$ 0.311$ million. The Table also shows that mean of the square root of research and development expenditures are 4.413 million, mean auditor market share is 23 percent, mean auditor tenure is 7.3 years and about 50 percent of client firms have effective audit committees. TABLE 2 presents the Pearson correlation matrix, which shows that there are generally no large correlations between the variables. ${ }^{4}$ 
Table 1

Data Collection and Descriptive Statistics

Panel A. Data Collection Procedures

\begin{tabular}{llll}
\multicolumn{1}{c}{ Procedures } & & N \\
\hline All Active Firms in Compustat (Excluding ADR) & & 9,488 \\
Auditors in 2000 and 1999 in Compustat & & 7,538 \\
Fiscal Year End (Jan Mar 2001, Oct $\sim$ Dec 2000) & & 6,030 \\
Excuding Financial Institution & & 5,286 \\
Availability of Financial/Auditor Variables & & 1,631 \\
Availability of Proxy Statement & & 1,081
\end{tabular}

Panel B. Descriptive Statistics

$\mathrm{N}=1,081$

\begin{tabular}{lrrrr}
\multicolumn{1}{c}{ Variables } & \multicolumn{1}{c}{ Mean } & & \multicolumn{1}{c}{ Median } & \\
\cline { 1 - 1 } ITFEE & 0.4348 & 0.0000 & & 2.9309 \\
R\&D & 4.4128 & 0.0000 & \\
INDSPLST & 0.2338 & 0.2108 & 0.1361 \\
AUDTEN & 7.3774 & 5.0000 & 6.6604 \\
DACCR & -0.0006 & -0.0005 & 0.5014 \\
ACEFF & 0.5032 & 1.0000 & 0.5002 \\
COMPLXY & 2.7438 & 3.0000 & 1.8379 \\
OTHFEES & 0.3109 & 0.1881 & 1.2302 \\
SIZE & 7.2713 & 7.0826 & 1.4724 \\
ROE & 1.3160 & 4.1610 & 30.3421
\end{tabular}

\footnotetext{
Variable definitions:

ITFEE $=$ Information systems design and implementation consulting fees paid to incumbent auditors.

$R \& D=\quad$ Square root of research and development expenditures.

INDSPLST = Auditors' industry market share, measured based on clients' sales revenue.

$A U D T E N=$ Auditor tenure, which is the number of years that an auditor remains with the same client firm.

$D A C C R=\quad$ Abnormal accruals measured based on the Modified Jones Model (Dechow et al. 1995).

$A C E F F=$ Audit committee effectiveness, which is 1 for firms that do not have employee or gray directors in their audit committees and meet at least twice during the year, and 0 otherwise.

COMPLXY $=$ Number of business segments.

OTHFEES = Natural log of audit and other fees combined paid to auditors.

$S I Z E=\quad$ Natural log of total assets.

$R O E=\quad$ Return on equity.
} 
Table 2

Pearson Correlation Among Independent Variables $\mathrm{N}=1,081$

\begin{tabular}{|c|c|c|c|c|c|c|c|c|}
\hline & INDSPLST & AUDTEN & $D A C C R$ & $A C E F F$ & COMPLXY & OTHERFEES & SIZE & $R O E$ \\
\hline$R \& D$ & $\begin{array}{c}0.0323 \\
(0.287)\end{array}$ & $\begin{array}{c}0.0748 \\
(0.013)\end{array}$ & $\begin{array}{r}-0.0356 \\
(0.242)\end{array}$ & $\begin{array}{l}0.0657 \\
(0.030)\end{array}$ & $\begin{array}{l}0.1093 \\
(0.000)\end{array}$ & $\begin{array}{c}0.3687 \\
(0.000)\end{array}$ & $\begin{array}{l}0.2813 \\
(0.000)\end{array}$ & $\begin{array}{r}-0.0102 \\
(0.735)\end{array}$ \\
\hline INDSPLST & & $\begin{array}{r}-0.0097 \\
(0.749)\end{array}$ & $\begin{array}{r}-0.0159 \\
(0.600)\end{array}$ & $\begin{array}{l}0.0125 \\
(0.679)\end{array}$ & $\begin{array}{l}0.0610 \\
(0.044)\end{array}$ & $\begin{array}{r}0.2109 \\
(0.000)\end{array}$ & $\begin{array}{l}0.1894 \\
(0.000)\end{array}$ & $\begin{array}{l}0.0006 \\
(0.983)\end{array}$ \\
\hline AUDTEN & & & $\begin{array}{l}0.0177 \\
(0.560)\end{array}$ & $\begin{array}{r}0.0254 \\
(0.402)\end{array}$ & $\begin{array}{l}0.1285 \\
(0.000)\end{array}$ & $\begin{array}{r}0.1106 \\
(0.000)\end{array}$ & $\begin{array}{l}0.1375 \\
(0.000)\end{array}$ & $\begin{array}{l}0.0696 \\
(0.021)\end{array}$ \\
\hline$D A C C R$ & & & & $\begin{array}{r}-0.0284 \\
(0.349)\end{array}$ & $\begin{array}{l}0.0584 \\
(0.054)\end{array}$ & $\begin{array}{r}0.0060 \\
(0.842)\end{array}$ & $\begin{array}{r}-0.0462 \\
(0.128)\end{array}$ & $\begin{array}{l}0.3351 \\
(0.000)\end{array}$ \\
\hline$A C E F F$ & & & & & $\begin{array}{r}-0.0449 \\
(0.139)\end{array}$ & $\begin{array}{l}0.1027 \\
(0.000)\end{array}$ & $\begin{array}{l}0.0879 \\
(0.003)\end{array}$ & $\begin{array}{r}-0.0082 \\
(0.787)\end{array}$ \\
\hline COMPLXY & & & & & & $\begin{array}{l}0.3761 \\
(0.000)\end{array}$ & $\begin{array}{l}0.3475 \\
(0.000)\end{array}$ & $\begin{array}{l}0.0678 \\
(0.025)\end{array}$ \\
\hline OTHERFEES & & & & & & & $\begin{array}{l}0.7619 \\
(0.000)\end{array}$ & $\begin{array}{l}0.0203 \\
(0.503)\end{array}$ \\
\hline SIZE & & & & & & & & $\begin{array}{l}0.0969 \\
(0.001)\end{array}$ \\
\hline
\end{tabular}

(p-value) is based on a two-tailed test.

Variable definitions:

$R \& D=\quad$ Square root of research and development expenditures.

$I N D S P L S T=$ Auditors' industry market share, measured based on clients' sales revenue.

AUDTEN $=\quad$ Auditor tenure, which is the number of years that an auditor remains with the same client firm.

$D A C C R=\quad$ Abnormal accruals measured based on the Modified Jones Model (Dechow et al. 1995).

$A C E F F=\quad$ Audit committee effectiveness, which is 1 for firms that do not have employee or gray directors in their audit committees and meet at least twice during the year, and 0 otherwise.

COMPLXY $=$ Number of business segments.

OTHFEES $=$ Natural log of audit and other fees combined paid to auditors.

SIZE $=\quad$ Natural log of total assets.

$R O E=\quad$ Return on equity.

\subsection{Regression Results}

TABLE 3 provides results of the regression using information systems consulting fees as the dependent variable. Consistent with the predictions, the coefficient of $R \& D$ is significant at all conventional levels, suggesting that firms spending more on research and development have higher demand for information systems consulting services. The coefficient on INDSPLST is positive and statistically significant at one percent level of testing, which is consistent with the expectation of positive association between industry expertise and demand for the ISC services. The coefficient on AUDTEN is also positive and statistically significant at five percent level of testing, suggesting that managers whose auditor has a long lasting relationship have higher demand for the ISC services.

The coefficients of most interest to regulators are $\beta 4$ and $\beta 5$, which are statistically insignificant. Inconsistent with the SEC and investors' concern, no association is found between client discretionary accruals and demand for the ISC services, suggesting that managers' reporting aggressiveness and audit committee effectiveness are not associated with demand for the ISC services. This may imply that effective audit committees are not concerned about a potential negative effect on auditor independence originated from purchasing auditors' ISC services. With regard to the CNTRL variables (number of business segments, other fees paid to auditors, firm size, and return on equity), a statistically significant coefficient on firm size is found. However, the number of business segment proxying for complexity, other fees paid to auditors, and return on equity are not statistically significant. ${ }^{5}$ 
Table 3

Determinants of Demand for Incumbent Auditors' Information Systems Consulting Services

\begin{tabular}{|c|c|c|}
\hline Variables & $\begin{array}{l}\text { Expected } \\
\text { Signs }\end{array}$ & $\begin{array}{c}\text { Estimated } \\
\text { Coefficients } \\
\text { (t-value) } \\
\mathrm{N}=1,081\end{array}$ \\
\hline Intercept & & $\begin{array}{l}-1.9593 \\
(-2.98)^{\star * *}\end{array}$ \\
\hline$R \& D$ & + & $\begin{array}{l}0.0793 \\
(6.93)^{\star \star \star}\end{array}$ \\
\hline INDSPLST & + & $\begin{array}{l}1.7282 \\
(2.71)^{\star \star \star}\end{array}$ \\
\hline AUDTEN & + & $\begin{array}{l}0.0218 \\
(1.69)^{\star *}\end{array}$ \\
\hline$D A C C R$ & + & $\begin{array}{r}0.1512 \\
(0.84)\end{array}$ \\
\hline$A C E F F$ & - & $\begin{array}{r}0.1606 \\
(0.94)\end{array}$ \\
\hline COMPLXY & + & $\begin{array}{r}0.0560 \\
(1.11)\end{array}$ \\
\hline OTHFEES & + & $\begin{array}{r}0.1405 \\
(1.24)\end{array}$ \\
\hline$S I Z E$ & + & $\begin{array}{l}0.1657 \\
(1.83)^{\star \star}\end{array}$ \\
\hline$R O E$ & - & $\begin{array}{r}-0.0031 \\
(-1.05)\end{array}$ \\
\hline F-value for Model & & $14.88^{* \star \star}$ \\
\hline Adjusted $\mathrm{R}^{2}$ & & 0.1037 \\
\hline
\end{tabular}

Significance of t-value is based on an one-tailed test. *,**, and *** indicate significance at the 10,5 , and 1 percent levels, respectively.

Variable definitions:

ITFEE $=$ Information systems design and implementation consulting fees paid to incumbent auditors.

$R \& D=\quad$ Square root of research and development expenditures.

$I N D S P L S T=$ Auditors' industry market share, measured based on clients' sales revenue.

$A U D T E N=$ Auditor tenure, which is the number of years that an auditor remains with the same client firm.

$D A C C R=\quad$ Abnormal accruals measured based on the Modified Jones Model (Dechow et al. 1995).

$A C E F F=$ Audit committee effectiveness, which is 1 for firms that do not have employee or gray directors in their audit committees and meet at least twice during the year, and 0 otherwise.

COMPLXY = Number of business segments.

OTHFEES = Natural log of audit and other fees combined paid to auditors.

SIZE $=\quad$ Natural log of total assets.

$R O E=\quad$ Return on equity

\subsection{Sensitivity Tests}

One concern with the above test is whether the results were driven by a relatively large proportion of sample that did not purchase the information systems consulting services while purchasing other services. While 99 percent of the sample firms reported positive non-audit fees, 86 percent of the sample firms reported zero ISC services fees. In order to examine if large proportion of the sample firms that reported zero information systems consulting 
fees may have affected the results, a logit regression is conducted. Firms that have reported positive ISC fees are matched with the firms that have provided fee data, but have reported zero ISC fees, based on two digit SIC industry code, auditor, and size of assets. The logit regression shows qualitatively similar results to the OLS regression.

Table 4

Logit Estimates: Determinants of Demand for Incumbent Auditors' Information Systems Consulting Services

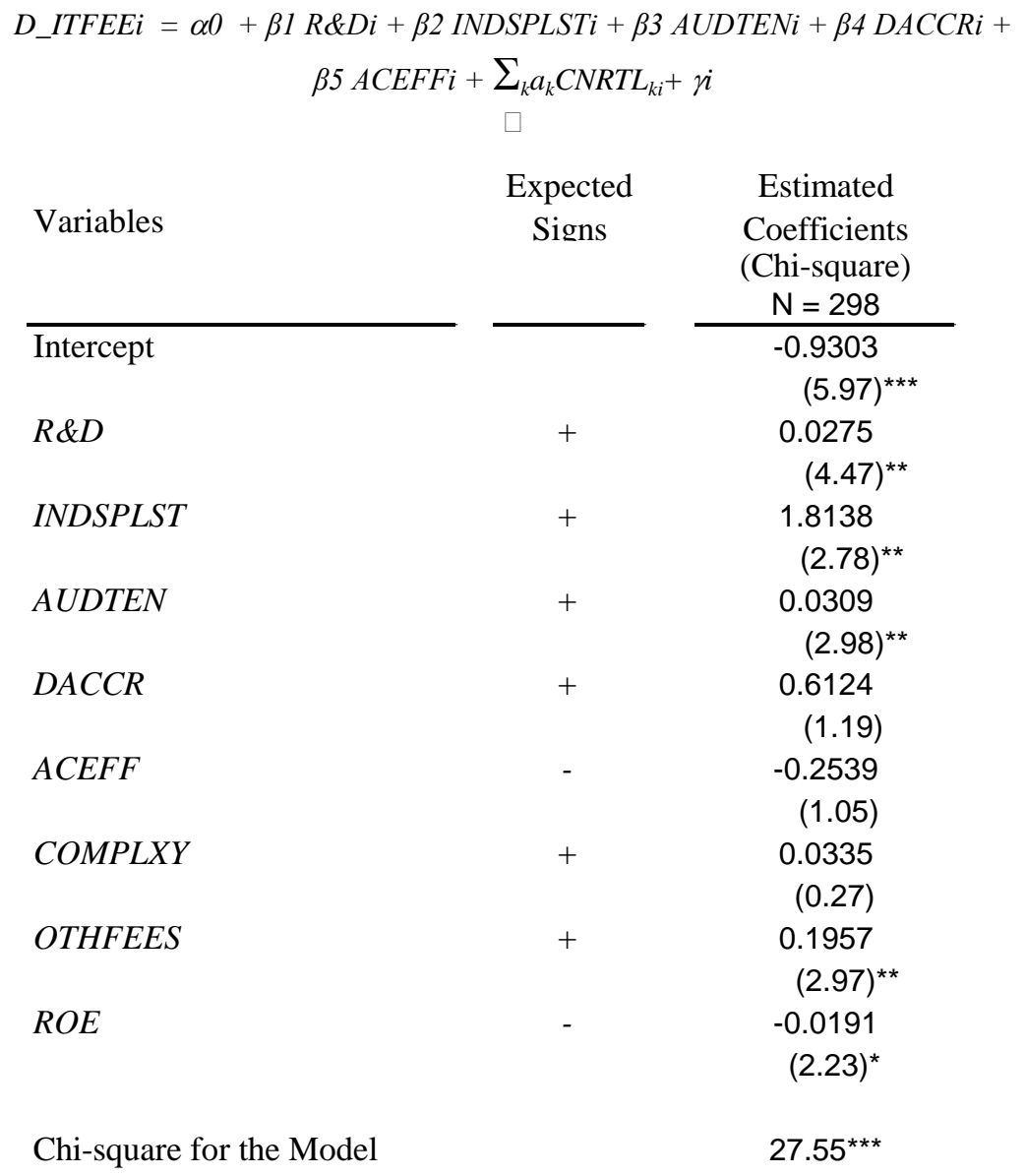

Significance of Chi-Square is based on an one-tailed test. *,**, and *** indicate significance at the 10, 5, and 1 percent levels, respectively.

Variable definitions:

$\overline{D \_I T F E E}=\quad$ The dependent variable coded 1 for firms with positive information systems design and implementation consulting fees paid to incumbent auditors, and 0 for no information systems fees.

$R \& D=\quad$ Square root of research and development expenditures.

$I N D S P L S T=$ Auditors' industry market share, measured based on clients' sales revenue.

$A U D T E N=$ Auditor tenure, which is the number of years that an auditor remains with the same client firm.

$D A C C R=\quad$ Abnormal accruals measured based on the Modified Jones Model (Dechow et al. 1995).

$A C E F F=$ Audit committee effectiveness, which is 1 for firms that do not have employee or gray directors in their audit committees and meet at least twice during the year, and 0 otherwise.

COMPLXY = Number of business segments.

OTHFEES = Natural log of audit and other fees combined paid to auditors.

$R O E=\quad$ Return on equity. 
Several additional tests for sensitivity analysis are performed and the results are summarized below. First, due to high correlation between other fees paid to auditors (OTHERFEE), and firm size $(S I Z E)(\rho=0.76)$, the results after eliminating one of these variables are examined. As expected, dropping one of these two variables slightly improves the statistical significances of other variables; however, the results are qualitatively unchanged. Variance influence factors (VIF) and condition indices (Belsley et al. 1980) indicated that multicollinearity among the explanatory variables was not a problem.

Second, when dichotomous variables of industry specialization are used instead of industry market share by auditors, the results are qualitatively the same. Third, when the absolute value of discretionary accruals instead of signed value of discretionary accruals is used, the results are qualitatively unchanged. Several different definitions of audit committee effectiveness are also examined. For example, three meetings instead of two meetings are required to define effective audit committees, which provides qualitatively similar results.

\section{Conclusion}

This study examines determinants of demand for incumbent auditors' information systems design and implementation consulting services. The results indicate that demand for the information systems consulting services is positively associated with the firms' research and development expenditures, which is consistent with the expectation that firms investing resources in information technology to enhance productivity also have higher demand for ISC services to improve information systems. Consistent with prior expectation, in general, there is higher demand for information systems consulting services toward industry specialist auditors and auditors with a long-term relationship. However, no association was found between demand for the information systems consulting services and client managers' accounting discretion or their audit committee effectiveness. The lack of significance for discretionary accruals and audit committee effectiveness may suggest that providing information systems consulting services by auditors may not necessarily reduce auditor independence. Collectively, the results may be consistent with Arrunada (1999) arguing that non-audit services can create client dependence on the auditor, rather than auditor dependence on the client.

While auditors' information systems consulting was of great interest to regulators and investors, there have been no empirical studies examining the association between various client and auditor characteristics and demand for the information systems consulting services. This study, therefore, contributes by providing useful information to both practitioners and policy makers on determinants of demand for incumbent auditors' information systems consulting services. This study is possibly relevant to a current debate among policy makers and auditors as to whether all or a part of non-audit services should be banned.

\section{Suggestions For Future Research}

Future research may increase the sample size particularly for firms that purchase both the information systems consulting services and other audit services. Other factors that have not been considered in this paper such as macro economic factors may also be related to demand for the information systems consulting. Therefore, the results should be interpreted subject to this caveat. In addition, due to data limitation, recurring and non-recurring information systems consulting services are not considered in this paper. ${ }^{6}$ More research is also needed to examine how auditors' information systems consulting services affect other quality aspects of financial reporting, such as number of restatements and going concern opinions, and litigation against auditors.

\section{Notes}

1. Audit committee members are considered gray directors if they are former employees of the company, relatives of officers, persons having business relationships with the firm, such as lawyers and investment bankers, or have any other types of affiliations.

2. Based on Palmrose (1986), an industry specialist is also defined as an auditor with the greatest market share or one with market share exceeding 15 percent within a two-digit SIC industry code. Another measure follows Abbott and Parker (2000) and Franz et al. (1998) who classify two-digit SIC code industries into 12 focus industries and define an industry specialist as one with the greatest market share or one with market share exceeding 15 percent within that grouping. Because results using both measures are qualita- 
tively similar, only the results using continuous market share as a proxy for industry specialization are reported.

3. Total accruals (TA) are: $T A i=(\triangle C A i-\triangle C L i-\triangle C A S H i+\triangle S T D i-D E P i) / A$ it-1, where $\triangle \mathrm{CA}$ is the change in current assets from t-1 to t; $\triangle \mathrm{CL}$ the change in current liabilities; $\triangle \mathrm{CASH}$ the change in cash and cash equivalents; $\triangle$ STD the change in debt included in current liabilities; DEP the depreciation and amortization expense; and At-1 the total assets at t-1. Using all firms on Compustat, for each year and two-digit SIC code we estimate the following model to obtain parameters a1, a2 and a3: TAi $=a 1(1 / A i t-1)+a 2$ $(\triangle R E V i)+a 3 P P E i+\varepsilon i$, where $\triangle \mathrm{REV}$ is the revenues in year $\mathrm{t}$ less revenues in year $\mathrm{t}-1$ scaled by total assets at $\mathrm{t}-1$, PPE is the gross property plant and equipment in year t scaled by total assets at $\mathrm{t}-1$ and $\varepsilon$ is the residual of the regression. We require that there be at least 15 observations (firms) in each industry-year regression. Next, using the estimated parameters a1, a2 and a3 we compute NDAPi for the subset of Compustat firms in our sample as follows: $N D A P i=a 1(1 / A i t-1)+a 2(\triangle R E V i-\triangle R E C i)+a 3 P P E i$ where $\triangle \mathrm{REC}$ is the net receivables in year $\mathrm{t}$ less net receivables in year $\mathrm{t}-1$ scaled by total assets at $\mathrm{t}-1$ and all other variables are as defined previously.

4. An exception is the correlation between SIZE and OTHERFEES $(\rho=0.76)$, which reduces the statistical significance of these coefficients (Studenmund 1992, p. 264). Further analysis for the effect of high correlation and multicollinearity is conducted in sensitivity tests section.

5. White's (1980) heteroskedasticity test indicates that the regression does not have heteroskedasticity problem.

6. For example, Parkash and Venable (1993) suggest the separation of recurring from nonrecurring non-audit services to examine the effect of knowledge spillovers from joint engagements.

\section{References}

1. Abbott, L. and S. Parker, "Audit Committee Characteristics and Auditor Selection," Auditing: A Journal of Practice and Theory, Vol. 19 (Fall), pp. 47-66, 2000.

2. __ , and _Audit Committee Characteristics and Auditor Switches," Research in Accounting Regulation, Vol. 15, pp. 151-166, 2001.

3. American Institute of Certified Public Accountants (AICPA), SEC Practice Section: Statement of Position Regarding Mandatory Rotation of Audit Firms of Publicly Held Companies, New York, AICPA, 1992.

4. Arrunada, B., The Economics of Audit Quality, Kluwer Academic Publishers, Boston, MA, 1999.

5. Banker, D., H. Chang, and Y. Kao, "Impact of Information Technology on Public Accounting Firm Productivity, working paper, University of Texas at Dallas, 2001.

6. Bartov, E., F. Gul., and Tsui, J., "Discretionary Accruals Models and Audit Qualifications, Journal of Accounting and Economics, Vol. 30, pp. 421-452, 2001.

7. Beasley, M. and S. Salterio, "The Relationship Between Board Characteristics and Voluntary Improvements in Audit Committee Composition and Experience, Contemporary Accounting Research, Vol. 18 (Winter), pp. 1-34, 2001.

8. Belsley, D., Kuh, E., and R. Welsch, Regression Diagnostics: Identifying Influential Data and Sources of Collinearity, John Wiley and Sons, New York, NY, 1980.

9. Chan, P., M. Ezzamel, and D. Gwilliam, "Determinants of Audit Fees for Quoted UK Companies," Journal of Business Finance \& Accounting, Vol. 20 (November), pp, 765-786, 1993.

10. Chung, H. and S. Kallapur, "Client Importance, Non-audit Services, and Abnormal Accruals," working paper, Purdue University, 2001.

11. Copley, P., M. Doucet, and K. Gaver, “A Simultaneous Equations Analysis of Quality Control Review Outcomes and Engagement Fees for Audits of Recipients of Federal Financial Assistance, The Accounting Review, Vol. 69 (January), pp. 244-256, 1994.

12. Craswell, A., J. Francis, and S. Taylor, "Auditor Brand Name Reputations and Industry Specializations, Journal of Accounting and Economics, Vol. 20 (December), pp. 297-322, 1995.

13. Davern, M., and R. Kauffman, "Discovering Potential and Realizing Value from Information Technology Investments, Journal of Management Information Systems, Vol. 16 (Spring), pp. 121-143, 2000.

14. Dechow, P. and R. Sloan, and A. Sweeney, "Detecting Earnings Management, The Accounting Review, Vol. 70 (April), pp. 193-225, 1995.

15. DeFond, M., J. Francis, and T. Wong, "Auditor Industry Specialization and Market Segmentation: Evidence from Hong Kong, Auditing: A Journal of Practice \& Theory, Vol. 19 (Spring), pp. 49-66, 2000. 
16. Franz, D., D. Crawford, and E. Johnson, "The Impact of Litigation Against an Audit Firm on the Market Value of Nonlitigating Clients," Journal of Accounting, Auditing \& Finance, Vol. 13 (Spring), pp. 117-134, 1998.

17. Geiger, M., and K. Raghunandan, “Auditor Tenure and Audit Reporting Failures," Auditing: A Journal of Practice \& Theory, Vol. 21 (March), pp. 67-78, 2002.

18. Greenberg, J., and R. Baron, Behavior in Organizations, Prentice Hall, Upper Saddle River, NJ, 1997.

19. Knapp, M., "Auditor Conflict: An Empirical Study of the Perceived Ability of Auditors to Resist Management Pressure," The Accounting Review, Vol. 60 (April), pp. 202-211, 1985.

20. Lang, M., and R. Lundholm, “Cross-sectional Determinants of Analyst Ratings of Corporate Disclosures, Journal of Accounting Research, Vol. 31 (Autumn), pp. 246-271, 1993.

21. Levitt, A., "The Accountant's Critical Eye," Remarks of Chairman at the $24^{\text {th }}$ Annual National Conference on Current SEC Developments, AICPA, Washington, D.C., 1996.

22. Lucas, H., and D. Berndt, and G. Truman,. "A Reengineering Framework for Evaluating a Financial Imaging System," Communications of the ACM, Vol. 39 (May), pp. 86-96, 1996.

23. Meixner, W., and R. Welker, "Judgment Consensus and Auditor Experience," The Accounting Review, Vol. 63, No. 3 (July), pp. 505-513, 1988.

24. Menon, K. and J. Williams, "The Use of Audit Committees for Monitoring," Journal of Accounting and Public Policy, Vol. 13, No. 2, pp. 121-139, 1994.

25. Palmrose, Z., “Audit Fees and Auditor Size: Further Evidence,” Journal of Accounting Research, Vol. 24 (Spring), pp. 97-110, 1986.

26. Parkash, M., and C. Venable, “Auditee Incentives for Auditor Independence: The Case of Nonaudit Services," The Accounting Review, Vol. 68 (January), pp. 113-133. 1993.

27. Securities and Exchange Commission (SEC), "Hearing on Auditor Independence," September 21, 2000, http://www.sec.gov/rules/extra/audmin4.htm, 2000a.

28. _ "Proposed Rule: Revision of the Commission's Auditor Independence Requirements," 17 CFR Parts 210 and 240 (Release Nos. 33-7870; 34-42994; 35-27193; IC-24549; IA-1884; File No. S7-13-00). SEC: Washington, DC, 2000b.

29. _ "Final Rule: Revision of the Commission's Auditor Independence Requirements. (Release Nos. 33-7919; 34-43602; File No. S7-13-00). SEC: Washington, DC, 2000c.

30. Shockley, R., "Perceptions of Auditors' Independence: An Empirical Analysis," The Accounting Review, Vol. 56 (October), pp. 785-800, 1981.

31. Sougiannis, T., "The Accounting Based Valuation of Corporate R\&D," The Accounting Review, Vol. 69 (January), pp. 44-68, 1994.

32. St. Pierre, K., and J. Anderson, "An Analysis of the Factors Associated with Lawsuits Against Public Accountants," The Accounting Review, Vol. 59 (April), pp. 242-263, 1984.

33. Studenmund, A., Using Econometrics: A Practical Guide, HarperCollins, New York, NY, 1992.

34. Taylor, M., "The Effect of Industry Specialization on Auditors' Inherent Risk Assessments and Confidence Judgments," Contemporary Accounting Research, Vol. 17 (Winter), pp. 693-712, 2000.

35. White, H, " A Heteroskedasticity-consistent Covariance Matrix Estimator and a Direct Test for Heteroskedasticity," Econometrica, pp. 817-838, 1980. 
Notes 